\title{
Inne widma
}

Maciej A. Sosnowski

TEKSTY DRUGIE 2016, NR 2, S. 324-342

DOI: $10.18318 /$ td.2016.2.17

W swej słynnej analizie powszechnego bytowania, które ma zrazu charakter Się, Heidegger odkrywa trzy fenomeny otwartości owego Się, które kształtują codzienność naszej upadłej egzystencji. Oprócz gadaniny i ciekawości mówi tam o dwuznaczności. Czym jest owa dwuznaczność?

Dwuznaczność jest sposobem, w jaki Się broni się przed tym, co zupełnie nowe i inne. W dwuznaczności arogancja miesza się z głupotą, które każą każdemu zaskakującemu wydarzaniu jawić się formie czegoś znajomego i oczywistego - nawet w swej nowości czy odrębności. Jak pisze Heidegger: „Dwuznaczność publicznej wykładni podaje rozstrzyganie już z góry i ciekawskie przeszukiwanie za właściwe wydarzenia, a przeprowadzanie czegoś i działanie opatruje etykietą czegoś wtórnego i nieważnego"1. Za sprawą powszedniej dwuznaczności sprawy mające pewną istotność i wagę stają się czymś miałkim i nieinteresującym, już
Maciej A. Sosnow-

ski - doktor filozofii, adiunkt w IFiS PAN, autor Pokochać dialektykę.

1 M. Heidegger Bycie i czas, przeł. B. Baran, PWN, Warszawa [b.r.w.], s. 223. 
z góry rozpoznanym i oswojonym czy przyswojonym, natomiast sama błahość takiego podejścia prezentuje się jako pełna żywotności i pomysłowości „mądrość".

Przede wszystkim jednak dwuznaczność blokuje prostotę bycia naszej egzystencji. Wszystko zawsze może być inne niż jest to nam prezentowane, fundamentalna jasność rozpoznawania właściwych możliwości bycia jest zaciemniona i rozmazana. Wszystko staje się przedmiotem do obgadywania, roztrząsania, porównywania i zrównywania w dwuznaczności, i „dlatego też rozumienie jestestwa w Się ciągle przeocza w swoich projektach prawdziwe możliwości bycia"2.

Jak wiadomo, najwłaściwszą taką możliwością jest bycie-ku-śmierci, zdecydowane wybieganie ku nam samym w naszej skończoności. Ale właśnie prostota takiego zdecydowanego projektu, jego, mówiąc wprost, bezpośrednia tożsamość z samym sobą, jego autonomia i suwerenność nieustannie są podminowywane przez dwuznaczność ciekawości i gadaniny: „Śmierć? Ech, znam, znam, nic interesującego, umiera się i już...", itd. Jak w dużo późniejszych już partiach tekstu opisuje rodzący się tutaj konflikt Heidegger: „Im bardziej właściwie jestestwo się decyduje, tzn. na podstawie swej najbardziej własnej, wyróżnionej możliwości niedwuznacznie rozumie się w wybieganiu w śmierć, tym bardziej jednoznaczne i nieprzypadkowe jest wybierające znajdowanie możliwości jego egzystencji. Tylko wybieganie w śmierć odpędza wszelką przypadkową i pobieżną możliwość. [...] Uchwycona skończoność egzystencji wyrywa z bezkresnej rozmaitości nasuwających się najbliższych możliwości samozadowolenia, beztroski czy wygodnictwa i wprowadza jestestwo w prostotę jego losu"3.

Wygodnictwu tego, co nieustannie dwuznaczne, przeciwstawione są więc jednolitość i prostota tego, co w zdecydowaniu ujawnia się w swej bezpośredniej jednoznaczności. Ta jednoznaczność, skryta zrazu przed ciekawością powszedniości, ów prosty, decydujący i zdecydowany fenomen tego-tu-oto, ta nasza niemożliwa ostatecznie do przegadania śmierć, jest kluczem do tego, co najwłaściwsze dla nas i nam.

Krytyka dwuznaczności i afirmacja bezpośredniej prostoty zdecydowanej decyzji jest trwałym rysem egzystencjalnych analiz Heideggera. Ale, co ciekawe, w innym kontekście dwuznaczność - również nieco odmieniona - okazuje się nie tylko powszednim fenomenem niewłaściwej egzystencji,

2 Tamże, s. 223.

3 Tamże, s. 482. 
ale w pewnym sensie kluczową, ontologiczną kategorią, odpowiedzialną za metafizyczne zapomnienie bycia, za los świata. To już nie kwestia „psychologii”, ale „struktur rzeczywistości”.

Otóż w swej skrupulatnej interpretacji „Wstępu” do Fenomenologii ducha, czyli w późnym eseju Heglowskie pojęcie doświadczenia, Heidegger w decydującym momencie przywołuje pojęcie dwuznaczności, które staje się terminem organizującym myśl dialektyczną, z istoty dwuznaczną.

Jak pamiętamy, Hegel w swych wprowadzających do Fenomenologii uwagach omawia to, co sam będzie rozumiał przez pojęcie „doświadczenia”: „Ten ruch dialektyczny, w który świadomość siebie wprawia, będący zarówno ruchem jej wiedzy, jak i jej przedmiotu, jest właśnie tym, co nazywa się doświadczeniem - o ile w wyniku tego ruchu wyłania się dla świadomości nowy prawdziwy przedmiot"4. Nie wnikając zbyt głęboko w splątany gąszcz znaczeniowy przytoczonego cytatu, możemy jednak podkreślić, że sam proces doświadczania, metamorfoza podmiotu-wiedzy i przedmiotu-prawdy i ich wzajemne przenikanie się są możliwe tylko dlatego, że już wcześniej Hegel zakłada pewną szczególną cechę badającej świadomości, a mianowicie, że „Świadomość ma swój wzorzec w sobie samej"5. Cóż to miałoby znaczyć?

Świadomość w swej podróży od jedynie-wiedzy do prawdy tej wiedzy musi ową wiedzę (to, co jedynie dla świadomości) porównywać z zakładaną prawdą (z tym, co samo w sobie). Aby mogła tego dokonać, potrzebny jest jej jednak jakiś „obiektywny” wzorzec, miernik, który pozwoliłby odnosić do siebie i porównywać ową „immanentną” jej samej wiedzę i „transcendującą" ją prawdę. Jednakże, skoro owo samo-w-sobie, „transcendencja” sama, istnieje w swym istotnym momencie dla świadomości, a więc sytuuje się zrazu na tej samej płaszczyźnie, co i wiedza (bycie-dla), to sama świadomość, która okazuje się tutaj płaszczyzną wszelkiego odnoszenia się, jest dla samej siebie miernikiem i wzorcem, pozwalającym odnosić się do swojego innego (prawdy), jak i odnosić się do tego odniesienia (być świadomością swojej prawdy), a więc być swoim innym w momencie samego odniesienia do innego (gdzie samo to odniesienie jest momentem innego konstytuującym). Świadomość jest więc w tym sensie samą podwójnością - jest zarówno momentem wiedzy, tzn. zakładającej swój przedmiot relacyjności, a także momentem separacji i zerwania, które domagają się uznania, oraz przede

4 G.W.F. Hegel Fenomenologia ducha, przeł. Ś.F. Nowicki, Aletheia, Warszawa 2002, s. 68.

5 Tamże, s. 66. 
wszystkim ruchem sprawdzania i doświadczenia - ruchem uznawania własnego założenia i zakładania własnego uznania, kiedy okazuje się, „że to, co przedtem było dla niej bytem samym w sobie, samo w sobie nie istnieje, czyli że istniało w sobie tylko dla niej"6.

Znowu zarzucając próbę klarowniejszego rozwikłania tego spekulatywnego węzła, pozostaje nam jedynie podkreślić to, co istotne w horyzoncie naszych rozważań - świadomość jest zarówno sobą, jak i nie sobą, jest swym innym, jak i sobą w tym innym. Jest sprawdzającym podmiotem, sprawdzanym przedmiotem oraz zewnętrznym miernikiem, pozwalającym na ruch odniesienia tych dwóch momentów. Jest dziejącą się, niepotrafiącą się w sobie samej zasklepić - ani w swym „formalnym” odniesieniu wszystkiego do świadomości, ani w równie pustym, niekomunikowalnym „w-sobie" czystego uznania - dynamiką dziania się pewnej „pierwotnej” dwójni siebie-i-nie-siebie.To, że świadomość jest swym miernikiem, wyznacza jej nieusuwalną, niezmordowaną, żywą dwuznaczność. Ten właśnie wątek można potraktować jako centralny w analizach Heideggera. Jak sam pisze - „Dwuznaczność odpowiada za to, że w świadomości wszędzie występują bezpośrednio oba określenia, wiedza i prawda, «bycie dla» «bycie w sobie» - ale przy tym one same są dwuznaczne"7.

Ta pełna niepokoju dwuznaczność świadomości, jak się zdaje wcześniejsza niż odróżnienie świadomości naturalnej i filozoficznej, nie jest „niedostatkiem jednoznaczności”, ale „znamieniem własnej istotowej jedności świadomości”, która w tym, co dwuznaczne, „ukazuje przynależność wza-

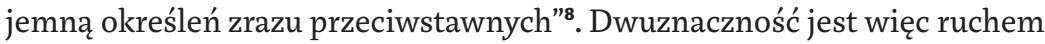
dialektyki, znoszącym w pewnej dziejącej się jedni separację nie-prawdziwych momentów skrajnych, przeciwstawnych. Dialektyka jest dwuznacznością - swego ruchu i samej siebie jako zatrzymującego znoszenia i znoszenia wszelkiego zatrzymania.

Ale taka dwoistość nie jest li tylko przypadkowym określeniem ważnej kategorii na gruncie filozofii heglowskiej, a pewnym świadectwem - świadectwem losu metafizyki w jej myśleniu bycia i różnicy ontologicznej. Sam Heidegger w dwuznaczności widzi istotowy rys tejże metafizyki, kiedy zauważa, że „Dwuznaczność owego òv obejmuje zarówno to, co obecne jak

6 Tamże, s. 67.

7 M. Heidegger Heglowskie pojęcie doświadczenia, przeł. R. Marszałek, w: tegoż Drogi lasu, Aletheia, Warszawa 1997, s. 138.

8 Tamże, s. 139. 
i uobecnianie się. Obejmuje oba naraz i żadnego jako takiego. [...] Jeśli istotę metafizyki pomyślimy w wynurzaniu się dwoistości obecnego i obecności ze skrywającej się dwuznaczności òv - a takie pomyślenie okaże się konieczne - to początek metafizyki zbiega się z początkiem zachodnioeuropejskiego myślenia" .

Dialektyka to metafizyka dwoistości (serii dwoistości: tożsamości tożsamości i nietożsamości, nietożsamości tożsamości i tożsamości, nietożsamości tożsamości i nietożsamości), dwoistości, która skrywa i w tym skrywaniu myśli - jak gdyby „na końcu języka”, „między wierszami” - źródłową dwuznaczności owego „tajemniczego” òv. I już u źródła, a nie w ramach późniejszych reinterpretacji owej dwoistości (zmysłowość i nadzmysłowość itd.), metafizyka, jakkolwiek daje wybrzmieć pewnej istotowej nieskrytości, jest skrywaniem tego, co istotowe, samego „istoczenia”. A nawet czegoś zaprzeszłego względem istoczenia; kiedy Heidegger próbuje pomyśleć, co tutaj istoczy w tym istoczeniu, co się w nim skrywa w dziejach metafizyki/ dialektyki/dwoistości, przekracza granicę filozofii i przybywa na terytorium poezji, jak choćby w eseju o Parmenidesie, kiedy pisze o Moirze, Udzielnej, która „przydzielając, rozdziela i w ten sposób rozwija dwoistość. Udzielna obsyła (zaopatruje i obdarza) dwoistością. Jest skupionym w sobie, a przeto rozwijającym przesłaniem wyistaczania czegoś wyistaczającego się. [...] jednak w przesłaniu dwoistości jawi się tylko wyistaczanie, a przejawia się tylko coś wyistaczającego się. Przesłanie zatrzymuje dwoistość jako taką i jej roz-

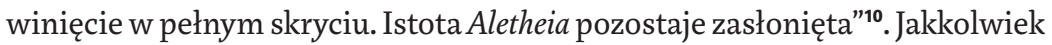
zdani jesteśmy na myślenie jako dzielącą i zbierająca dwójnię, (dialektykę) to choć myślenie owo zostało nam udzielone i udzielone przez to, co istoczy, to jednak w takim właśnie myśleniu sprawa jest już przesądzona - jest ono skrywaniem, ponieważ dwójnia jako taka nie jest w stanie pomyśleć rzetelnie nieskrytości tego, co w istoczeniu istoczy. Myślenie w swej dwoistości - bez względu na to, jaką formę dwoistość ta przyjmie - nie może oddać sprawiedliwości temu co „aleteicznie istotne”; temu, co chce pomyśleć, właśnie ze względu na swą dwoistość, która zawsze musi skrywać, bo musi „być już czymś, czym jednocześnie jeszcze nie jest"11.

9 Tamże, s. 145 .

10 M. Heidegger Moira, przeł. J. Mizera, w: tegoż Odczyty i rozprawy, Aletheia, Warszawa 2007, S. 248 .

11 M. Heidegger Heglowskie pojęcie doświadczenia, s. 150. 
Zostawmy jednak tę zagadkową mowę. Tym, co dla nas może być tutaj ważne, to fakt, że pod egidą pewnej dwoistości zbierane są i ujedniane dialektyka, myślenie, metafizyka. Całość tego, co filozoficzne i przed-filozoficzne, jest określane jako istotowo dwuznaczne. A jeśli przypomnimy, że sama „istotowość" jest skrajnym momentem pewnej dwójni - istoty i pozoru, istoty i przejawu, istoty i istnienia itd. - to sama ta istota, sama dwuznaczność, okaże się dwuznaczna. I to jest wniosek z heideggerowskiej lekcji na temat Hegla i filozofii zachodu ogóle, że trapi ją dwuznaczność, która sama jest dwuznaczna (zgodnie z heglowskim określeniem absolutu jako tożsamości, która jest nietożsama), tzn. że sama ta dwuznaczność, która zbiera i określa ruch myśli, jest w nieustannym ruchem siebie samej.

Ale czy taka dwoistość, dwuznaczność (we wszelkich swych formach, od potocznej świadomości po „ontologizującą" wiedzę absolutną), powiedzmy więcej, taka „metafizyczna" nietożsamość tego, co ujedniające, nie ma charakteru tego, co później Derrida określał mianem „widma”? Czy filozofia nie jest, jako dziejąca się dwójnia myślenia, które myśli siebie jako niepomyślane i nigdy nie może domyśleć się siebie i rozłożyć na statyczne i tożsamościowe kategorie siebie samego, otóż, czy to nie jest właśnie dokładne - a więc dwuznaczne - określenie „widmologii”? Czy metafizyka nie jest „u zarania” swym własnym widmem?

Przede wszystkim jeśli weźmiemy na razie pod uwagę wczesną interpretację Hegla z Glas, to widać, jak Derrida podąża śladami Heideggera. Kiedy zapytuje: „Jak może pojawić się to, co swoje i to, co dla siebie?”"12, tzn. jak może ustanowić się dialektyczna dwuznaczność subiektywności, i kiedy, na gruncie analizy religii istoty słonecznej z Fenomenologii, odpowiada, że:

Tutaj doświadczamy nieprzejednanej mocy sensu, mediacji, ciężkiej pracy negatywności. Aby stać się tym, czym jest, czystość gry, czystość różnicy, czystość pochłaniającej destrukcji, wszechspalanie musi przejść w swe przeciwieństwo: zacząć siebie strzec, strzec swój moment zatraty, pojawić się takim, jakim jest w swym zanikaniu. I kiedy tylko pojawi się jako takie, kiedy tylko ogień ukaże sam siebie, kiedy siebie zachowa, zatraci siebie jako ogień. Czysta różnica, różna od swojości siebie, odmawia bycia sobą aby pozostać tym, czym jest. Oto źródło historii, początek zachodzenia,

12 J. Derrida Glas, trans. J.P. Leavey, jr., R. Rand, University of Nebraska Press, Lincoln-London 1986, S. 239. 
zachód słońca, przejście do zachodniej subiektywności. Ogień staje się dla-siebie i przepada ${ }^{13}$,

to widzimy tutaj ten sam schemat rozumienia dwójni myślenia, który obecny był u Heideggera. Pewna „źródłowość” udziela się i w tym udzielaniu rozpętuje dwuznaczność, która zaczyna władać myśleniem, jest myśleniem czystości tej „źródłowości”, ale jako dwójnia właśnie jest w tym myśleniu jej zapominaniem, jej zagładą, jej skrywaniem. Dwuznaczność dialektyki polega więc na upartym i bezwiednym przypominaniu tego, co w samym procesie przypominania jest zacierane i zapominane. I, póki co, tylko na tym.

Ale w późniejszym tekście, już określonym przez horyzonty widmologii, Derrida przywołuje tę swoją interpretację, sugerując nieżyczliwemu czytelnikowi subtelną reafirmację owego myślącego rozdwajania. W O duchu czytamy: „Hegel, który - jak starałem się wykazać gdzie indziej - sytuował przejście od filozofii natury do filozofii ducha w tym spalaniu, z którego, niczym wzniosły wyziew fermentacji, Geist - gaz - wznosi się lub ponownie wznosi ponad martwych w stanie rozkładu, żeby się uwewnętrznić w Aufhebung"14.

Cytat ten i jego analiza niosą ze sobą pewne ryzyko, zatem należy być tutaj ostrożnym. Martwotą, ponad którą wznosi się duch, jest sama naturalność jako pewna autonomiczna czy też roszcząca sobie pretensję do autonomii, sfera rzeczywistości. Owa naturalność jest bezpośredniością tego co jest, jest ową czystością wsobnego odniesienia do siebie, bez mediacji i zapośredniczenia. Jest absolutną tożsamością - iluzyjną, ale nieuświadomioną przez naturalność - czystości samej różnicy, o której pisał Derrida w Glas. Ta pustka tożsamości - klasycznie rozumiana, metafizyczna obecność absolutnej autonomii - umiera, spala się w pustej grze ze sobą, zanika w swej nieokreśloności. Jej śmierć, śmierć tożsamości bez relacji do innego, pozwala jej odżyć po śmierci pod postacią "ducha”, który unosi się nad nią jako ferment jej samej. Taki „duch” to „początek” dialektyki i dwójni - życia po śmierci tego, co naturalne, co tylko jest-jako-to-oto. „Duch” ów jest więc życiem naturalnej bezpośredniości w jej zaniku i umieraniu. „Duch” jest powidokiem tego, co obecne i tożsamościowe. „Duch” jest - jak chcemy to tutaj zasugerować zrazu i zawsze widmem, a nasza sugestia podąża za słowami samego Derridy

Tamże, s. 240.

14 J. Derrida O duchu, przeł. B. Brzezicka, PWN, Warszawa 2015, s. 113. 
z tego samego tekstu, kiedy pisze on, że „Geist jest zawsze nawiedzany przez swój Geist"15.

Wróćmy więc do pytania: czym jest widmo? W powyższych rozważaniach pojawiło się pewne podwojenie ducha, które związane było z jego własną genezą i z rozproszeniem tego, co o „duchowości” ducha w tradycji metafizycznej jest decydujące, tzn. z autonomiczną tożsamością. Duch nawiedzający ducha to duch, który rozpulchnia i fermentuje umierającą bezpośredniość ducha pierwszego rzędu, jeśli można tak powiedzieć. Ten drugi duch, duch nawiedzenia, to właśnie widmo - ale duch jest zawsze swym drugim, swym nawiedzeniem, swym widmem, bo bezpośredniość, chciałoby się rzec, umiera przed czasem i w tym, co się staje, już nigdy jej nie ma. Jak Derrida pisze w Widmach Marksa - „komunizm zawsze był i pozostanie widmowy: zawsze dopiero nadchodzi i odróżnia się, niczym demokracja, od każdej żywej obecności rozumianej jako pełnia uobecniania-się-dla-siebie, jako totalność obecności tożsamej ze sobą" ${ }^{16}$. Widmo nie jest więc tego typu tożsamością ze sobą - widmo nie jest bezpośredniością czystej różnicy, o której pisaliśmy powyżej, sama zaś bezpośredniość, tak rozumiana, jest jedynie ideologiczną iluzją, fałszywą świadomością, mającą moc tylko jako ideologia.

Widmo przeżywa martwotę takiego ducha (ducha, którego nigdy nie było). Czysta różnica, choćby była różnicą „będącą” w tym, co autonomicznie-naturalne, zawsze musiałaby „być” czymś duchowym jako tożsamość-bez-innego. Pełna siebie natura byłaby duchowa - nie w sensie „spirytualizacji”, ale w sensie pełnej obecności.

Widmo, choć jest efektem destrukcji i rozproszenia tak rozumianej bezpośredniości/duchowości/naturalności, ma jednak coś wspólnego z tą nie-rzeczywistością tego, co naiwnie-absolutne ${ }^{\mathbf{1 7}}$; po pierwsze - jest jedynym sposobem jawienia się „duchowości”, jest dzianiem się cielesności czy też raczej fenomenalną widzialnością tego, co odmawiało wszelkiej relacyjności, wszelkiego jawienia się: „[... zjawiskowa forma, fenomenalne ciało ducha, oto definicja widma [...]”18; po drugie zaś, sama ta „widzialność”, owo przybranie formy przez to, co istotowe nieforemne (absolutnie-bezpośrednie),

15 Tamże, s. 49.

16 J. Derrida Spectres of Marx, trans. P. Kamuf, Routledge, New York 1994, S. 123.

17 Por. tamże, s. 5 .

18 Tamże, s. 169. 
jest możliwa tylko jako śmierć, dynamiczna i dokonana, nigdy niemająca miejsca i czasu, a jednak w zaprzeszłości wydarzająca się, śmierć amorficznej duchowości ducha, jego idiotycznej i nieporównywalnej z niczym tożsamości. Widmo to nieustanna relacja - niemożliwa i dlatego nawiedzająca - do martwoty owej tożsamości: „Widmo jest nie tylko cielesnym widokiem ducha, jego fenomenalnym ciałem, jego upadłym i winnym ciałem, ale jest też niecierpliwym i nostalgicznym czekaniem na odkupienie [...]. Zjawa jest odwleczonym duchem, obietnicą czy też liczeniem na ekspiację"19. Widmo to, innymi słowy, już zawsze martwy duch, utrzymujące się przy swym ambiwalentnym trwaniu na mocy czegoś w rodzaju wyrzutów sumienia względem śmierci tego, co widmo powołało do życia - ducha.

Widmo jest więc istotową podwójnością - jest widzialnością tego, co niewidzialne, życiem tego, co umarło, zapośredniczeniem tego, co wzbrania się przed pośredniością, formą tego, co oddala wszelkie ukształtowanie. Jest jedynym, zawsze nieudanym i niepełnym sposobem, w jakim może dziać się to, co chciało być totalnością. Z innej strony: widmo jest „marnym” życiem tego, co istotne, co idealne. I to w dokładnie tym samym sensie - zarówno od strony własnej genealogii, jak i stawki, którą wyznacza o obrębie filozofii - co heideggerowska dwuznaczność, jako skrycie i zawsze nieudane przywoływanie tego, co, dwuznaczność ową „rozpętało”.

Skoro jednak widmo to porażka wszelkiej duchowości i zarazem jedyne, co z wszelkiej duchowości pozostaje, zawsze pozostaje, to widmo jest dzianiem się bezpośredniości (a jest to sprzeczność) - jako nieustannego zapośredniczenia w relacjach między wykluczającymi się sferami (życie śmierci, widzialność niewidzialnego). I tak, jak dwuznaczność widma ma rys heideggereowski, tak też widmologia wciąż uwikłana jest, choćby śladowo, w heideggerowską nostalgię - nostalgię za, nie boimy się tego powiedzieć, pełnią obecności zbawczego ducha. Nawet krytyka Marksa za jego fantazmat o rajskim świecie czystych wartości użytkowych nie broni Derridy przed zdradzaniem się z tęsknotą za owym mesjańskim, bezpośrednim, sprawiedliwym i absolutnie-pojedynczym „czymś”, co udzieliło podwójności temu, co widmowe i skryło się (niczym Moira w tekście Heideggera). To coś jest, owszem, niemożliwością, ale właśnie jako niemożliwość nawiedza.

Jak wyglądać by jednak miała dwójnia, która nie odsyła do pre-pierwotnego źródła ani nie ziszcza się w pleromatycznym spełnieniu? Owa,

Tamże, s. 170-171. 
wspominana choćby przez Agambena w Jezyku i śmierci, filozofia poza bezpośrednio-negatywnym „Głosem jako mistycznym ufundowaniem całej naszej kultury"20? Czym miałoby być widmo wyzbyte owej tęsknoty i pragnienia ekspiacji?

Podwójność widma i dwuznaczność dialektyki zbierane są również w pewnej dynamicznej koncepcji, którą prezentuje Catherine Malabou w swym odczytaniu Hegla.

Kłopot z widmowością, a także z dwuznacznością jest taki, że pojęcia te kreują pewien fantazmat własnej autonomii i substancjalizują się do postaci pewnego „czegoś”. Trudno jest mówić o widmie, nie sugerując się przy tym czasownikiem „jest”, że widmo rzeczywiście „jest”, jest tym-oto, jakimś czymś, co zostaje „dostawione” do tego, co jest nawiedzane. Również dwuznaczność nie unika pułapki „ujednoznaczniania” się - „dwuznaczność”, kiedy mówi się o niej jako o istocie dialektycznego przejścia, staje się jedynie pewnym „logicystycznym” określeniem. Substancjalizacje tych aspektów dialektyki, które w założeniu miały właśnie przed substancjalizowaniem ją bronić, nierzadko wykorzystywane są przez krytyków spekulacji, tudzież generują liczne niejasności (a zarazem są podglebiem wszelkich „nostalgiczno-romantycznych” aplikacji „metody” dialektycznej). Jak się zdaje, interpretacja Malabou stara się za wszelką cenę uwolnić spekulację od oddialektycznienia jej w takich formach, traktując dwuznaczność widmowości radykalnie poważnie.

Tym, na co chcielibyśmy zwrócić tutaj uwagę, jest nie tyle kwestia heglowskiej przyszłości, co jest akurat przedmiotem szczególnej uwagi Malabou (a kończy się wnioskami bliźniaczo podobnymi do tych, które znajdujemy np. u Adorna ${ }^{21}$ czy Hamachera ${ }^{22}$ ), ale jej „plastyczna” interpretacja samego rdzenia plastyczności, tzn. Aufhebung, jako węzła dwuznaczności, kryjącej się $\mathrm{w}$ dialektyce.

Przede wszystkim to, co zdaje się oczywiste, to fakt perfekcyjnego pokrywania się, bez wyjątków, wszelkich form dwuznaczności/podwójności i plastyczności. Już we wstępie czytamy: „Plastyczność jawi się jako proces,

G. Agamben Language and Death, trans. K.E. Pinkus, M. Hardt, University of Minnesota Press, Minnesota 2006, s. 91.

T.W. Adorno Skoteinos, or How to Read Hegel, w: tegoż Hegel. Three Studies, trans. S.W. Nicholsen, MIT Press, Cambridge MA 1993. 
w którym to, co ogólne i to, co pojedyncze wzajemnie sobie odpowiadają"23; „Plastyczny proces jest dialektyczny ponieważ operacje, które go konstytuują, to jest uchwytywanie formy i anihilacja wszelkiej foremności, zjawiania się i eksplozji, są wzajemnie sprzeczne"24, itd. Wniosek płynący z tej wstępnej ekspozycji chwyta w istocie sam esencję dialektyczności jako nieustannej serii przemian, gdzie to „Plastyczność jest punktem wokół którego krążą wszystkie heglowskie transformacje myśli, jest centrum ich metamorfoz" ${ }^{25}$.

W uszczegółowieniach, które wyznaczają rytm argumentacji Malabou, plastyczność wiąże się ze starożytnym modusem myślenia o człowieku i jego etyczności jako nawyku, a także z modusem nowoczesnym, gdzie kluczowe okazuje się chrześcijaństwo i wpisane w boską pleromę kenosis wcielenia i śmierci na krzyżu. Oczywiście oba te modusy mają plastyczny charakter. Nawyk (habitus) jest plastycznym zwornikiem tego, co naturalne i tego, co duchowe: „Nawyk tworzy wirtualny byt, działający jak termin środkowy tej opozycyjnej struktury [jedność ciała i duszy] i skraca dystans między sprzecznościami. Przemienione przez pracę nawyku dusza i ciało tworzą czujące medium ducha. Indywiduum jako pojedynczość, zrealizowana jedność formalnej ogólności duchowych określeń i partykularności somatycznych afektów, pojawia się w ramach procesu wzajemnej translacji między psychicznymi i cielesnymi manifestacjami. Odtąd indywiduum jest już ,indywiduum plastycznym"26. Natomiast kenosis, jako konkretna realizacja negatywności, tkwiącej w bezpośrednim Absolucie-Bogu, czyli jako wyzewnętrznienie (Entäußerung) i reprezentację, sugeruje, że „Boska, wewnętrzna negatywność nie może być dłużej interpretowana jako «pasywność», o ile nie chcemy tej pasywności traktować jako pasywności samego czasu. Ale jeśli pasywność czasu jest zarazem darem formy, to «plastyczność» okaże się tutaj iście trafionym słowem"27. Innymi słowy, wcielenie i śmierć, czyli kenotyczny proces tworzenia i znoszenia boskiej reprezentacji w tym, co pojedynczo-patologiczne, to nowożytny sposób ujmowania plastycznej relacji między skrajnościami.

23 C. Malabou The Future of Hegel. Plasticity, Temporality and Dialectics, trans. L. During, Routledge, London-New York 2005, s. 11.

Tamże, s. 13. 
Obie te formy plastyczności - starożytna i nowożytna, będące dwiema formami dwuznaczności samej, dwuznaczności podmiotu, ogólności, duchowości oraz przedmiotu, pojedynczości, cielesności, są zbierane w analizach dotyczących Wiedzy Absolutnej i figurze filozofa. Tym, co tutaj odgrywa szczególną rolę, to wspomniana wcześniej próba specyficznego zrozumienia tego, czym jest samo znoszenie jako pointa czy clou całej filozofii (jako serii plastycznych procesów) i plastyczne „przemieszanie” tego, co starożytne i nowożytne. W tym sensie Hegel jest filozofem, który, dzięki precyzyjnej i, jeśli można tak rzec, najbardziej podstawowej artykulacji plastyczności w ramach swej myśli, plastyczności nie tego czy innego momentu, nie tej czy innej opozycji, ale plastyczności ja ko plastyczności,jest filozofem, który wyrasta poza starożytność, nowożytność i ich opozycję. Jest filozofem nowego, będąc zarazem najgłębiej jak tylko się da zanurzony w tradycji (jest więc na wskroś filozofem plastyczności i zarazem filozofem plastycznym).

Zanim jednak Malabou przechodzi do plastycznej interpretacji znoszenia, stawia pytanie o klasyczne rozumienie tego terminu na gruncie heglizmu i na rodzący się wtedy kluczowy problem, związany również z dwuznacznością dialektyki i nieustannością nawiedzania przez widma: „Czyż nie jest tak, że ostatecznym wynikiem dialektycznego znoszenia jest zła nieskończoność? Czy znoszenie samo nie jest podmiotem nieustannej aktywności, która niweluje się w tej samej chwili, w której się ustanawia? I jeśli prawdą jest, że Wiedza Absolutna wyznacza punkt zatrzymania w dialektycznym rozwoju, to czy ta pa z a nie jest nieuzasadnionym, ale zupełnie realnym efektem pełnej przemocy, zewnętrznej interwencji?"28. Jest to zaiste problem kluczowy dla samej „formalnej” struktury myślenia dialektycznego. Jeśli dialektyka złej nieskończoności, czysta dialektyka negatywna, jest tak naprawdę próbą nieustannego ujednoznaczniania i tym samym wypaczania płynnej dwuznaczności spekulacji, ponieważ substancjalizuje moment negatywny w jego tożsamościowej bezpośredniości i prostocie, to jak rozumieć ową „rzetelną” spekulację, szczególnie w jej szczytowym punkcie, w Wiedzy Absolutnej, w tym rzekomym „zatrzymaniu”? Czy każda dialektyka jest skazana na negatywność własnej podstawy i reprodukcję ideologii tożsamości tudzież na martwotę, związaną ze statyczną afirmacją martwego systemu? Według Malabou - nie, i to właśnie dzięki plastycznemu rozumieniu Aufhebung. 
Sam pomysł na "uplastycznianie" znoszenia jest prosty. Aby dwuznaczność nie zastygła w punktowej jednoznaczności jakiejś mistycznej, preromantycznej dwójni, aby widmologia nie zamieniła się w stupor pustej nadziei tudzież w martwe pragnienie rezurekcji Ducha, tzn. aby dialektyka się nie kończyła, a jednak nie popadała w złą nieskończoność, potrzeba tylko jednej operacji - zniesienia samego zniesienia” „To, co musi być tutaj ukazane to to, że Hegel w istocie przywraca dialektyczną performatywność aufheben i Aufhebung, że w efekcie znosi on aufheben w Aufhebung, Aufhebung w Aufhebung"29.

Dwuznaczność dialektyki, jak już było powiedziane, sama musi stać się dwuznaczna w tym sensie, że samo znoszenie okazuje się nie tylko pewną pustą i zewnętrzną procedurą, zawiadującą ciągiem transformacji spekulatywnych treści, ale samo było swoją treścią, aby samo ulegało transformacji, aby było uczasowione, „stemporalizowane”; jak ujmuje to Malabou - musimy pamiętać, że „Aufhebung samo ma swoją historię"30; i dalej - „W filozofii Hegla, podwójne znaczenia Aufhebung jako stłumienia i zachowania samo musi mieć podwójne znaczenie" ${ }^{\text {31. }}$.

Pierwszym krokiem, pozwalającym na podwojenie podwojenia, jest coś, co Malabou określa mianem „uproszczenia”. Proces dialektyczny zbiera różnorodność zjawisk, które stara się pojednać w ramach jakiejś „inteligibilnej” matrycy. Taki charakter ma abstrakcja - w ramach spekulacji abstrahujemy do różnorodności, poszukując, niczym twórcza wyobraźnia transcendentalna u Kanta, pewnego pojęcia, formy czy postaci, która będzie epitomem i duchowym ujęciem tej „wszelakości” w czymś prostszym. Samo to „zbieranie” jest naszym rozumieniem. I, jak zauważa Malabou, „mimo narzucającego się wrażenia, trzeba zaznaczyć, że abstrakcja wcale nie jest jednoznacznie odbieraniem czemuś życia, bowiem może okazać się również siłą, która życie daje"32. Takie życie abstrakcji jest oczywiście życiem widmowym ponieważ jest życiem czegoś, co w procesie abstrahowania umarło, trwa jednak w nowej, ,prostszej” formie (pojęciu, obrazie, figurze).

Pochód dialektyki mierzony jest przez punkty, które ona tworzy i które mija: „W rozwoju ducha przejście do kolejnego stadium związane jest z redukcją tego stadium do pojedynczej, dominującej charakterystyki, pewnego

Tamże, s. 145.

Tamże.

Tamże, s. 146.

Tamże, s. 148. 
skrótu czy wyciągu, logicznego z n a k u"33. Poszczególne formy świadomości czy stadia ducha to zagęszczone wieloznaczności, sprowadzone do pewnej ogólnej, prostej formuły - religia, świadomość nieszczęśliwa, sylogizm, teleologia zewnętrznej celowości itp. Spekulacja rozpięta jest między takimi punktami.

Ten proces ujednania $i$,atomizacji” wielości - coś, co stanowiło nierzadko podstawę dla krytyki Hegla - u Malabou nie jakimś ukrytym i wstydliwym aspektem tej filozofii; jest jej rysem kluczowym, bowiem „podstawową tendencją wiedzy jest jej pogoń za kondensacją" ${ }^{\text {34 }}$. Uproszczenie to idealizacja i jednocześnie podwojenie, spektralizacja (Malabou kilka razy używa określenia „nawiedzenie" dla oddania specyfiki owego procesu).

Owe idealizujące kondensacje to momenty, w których nieukształtowana wielość uzyskuje formę. „Uproszczenie to forma grająca z formami” ${ }^{\text {, }}$, jak czytamy dalej. Tylko dzięki nadawaniu formy, tylko dzięki nasycaniu czegoś pewną dozą idealności, coś może zjawiać się i prezentować dla czegoś/kogoś. Uproszczenie, choć, oczywiście, upraszcza, to jednak w tym uproszczeniu tworzy. „Uproszczenie jest odpowiedzialne za określanie warunków pod jakimi coś obecnego może się zjawiać"36. Innymi słowy, nieokreślona magma zmysłowości zostaje zredukowana i skonfigurowana. Uzyskuje pewien skrót w formie, która jest przyswajalna - nie tyle dla ducha, ale w ogóle po raz pierwszy "dla czegoś” i dopiero w tym "dla-czegoś,, w tym powstałym w kondensacji odniesieniu, duch zaczyna sam siebie, dzięki swojej zawczasu wykonanej, bezwiednej niejako pracy kondensacji, pojmować i przyswajać. Skrót wielości jest konieczny, aby mogła się wytworzyć owa habitualna druga natura, którą jest sam duch. Duch sam siebie tworzy z własnej działalności jako ducha.

Jeśli pierwotnie duch jest jedynie ślepą, „naturalną" negacją tego, co neguje ducha, to dzięki idealizującym uproszczeniom - które są zatratą wielości, ale i zarzewiem nowej wielości - duch, w skrótach, sam zaczyna ożywać i siebie kształtować. Duch, dzięki martwej punktowości, ożywa jako swój własny inny, jako negacja negacji, którą dotąd był, jako życie po śmierci tego, co naturalne, jako widmo, jako zdwojenie siebie, jako kultura: „Dzięki

34 Tamże, s. 151.

35 Tamże.

36 Tamże, s. 152. 
uproszczeniom, duch redukuje swój własny opór, staje się bardziej giętki, elastyczny, uległy [...]. Uproszczenie wytwarza drugą naturę ducha, redukując pierwszą naturę do formy logicznych określeń, które stają się odtąd kontrakcją potencjalnej energii, czymś, co można posiadać [...]. Jeśli duch poświęca własną cielesność poprzez redukcję konkretnego bycia-tutaj-oto do uproszczonych określeń, to jednocześnie pozwala mu to na przyswojenie sobie spekulatywnej treści. Indywiduum «pochłania» kulturę jak gdyby to była «natura nieorganiczna» i w swej własnej egzystencji reprodukuje tę destrukcję, wpisaną w uproszczenie. To jedyny sposób, w jaki indywiduum może uwewnętrznić kulturę"37.

Duch to w zasadzie nieskończone pole konfiguracji punktów zagęszczeń, w których drzemie potencjalna energia tego, co w nich uległo kontrakcji. Taki duch to duch wyalienowany i alienujący, duch reprodukującej się kultury. Ale to również duch-widmo, wciąż żyjące w imaginarium pełnej bezpośredniości - bądź natury, bądź kultury.

Jeśli więc znoszenie musi znieść samo siebie, to duch, widmowy proces znoszenia, proces upraszczania jako rozłamywania rzeczywistości na dwie niepełne siebie bezpośredniości (natura/kultura), musi procedurę idealizacji odnieść do siebie samego. Musi stać się własnym uproszczeniem, musi poddać się procedurze skrótu, musi się uchwycić w sobie za pomocą siebie. Nie tylko stać się swym własnym innym, zanegować siebie, ale musi w swej własnej, „skróconej” inności poszukać inności tej inności i ją odnaleźć i tylko wtedy, kiedy uprości kluczowy aspekt własnego trwania - upraszczanie -będzie mógł siebie pojąć (pojąć sam proces pojmowania,jeśli można tak rzec).

Może się to dokonać jedynie w momencie, w którym samo znoszenie negacja negacji - zostaje stematyzowane, czyli w momencie pełnego przyswojenia tego, co uległo skrótowi, tzn. tylko wtedy, kiedy cały system jest, niczym mapa punktów, gotowy. Wiedza Absolutna jest właśnie takim momentem - momentem nie tyle pełnego opanowania treści, co wręcz przeciwnie - momentem, w którym treść jest uwalniana i nabiera nowego znaczenia, skoro sam proces nadawania znaczenia, proces upraszczania i znoszenia, sam ulega przemianie i nabiera nowej treści.

Finalny sylogizm Wiedzy Absolutnej, sylogizm filozofii, tak, jak prezentuje się w Encyklopedii nauk filozoficznych, opisuje „przyrodę jako proces idei

Tamże, s. 152-153. 
istniejącej jako coś samego w sobie, obiektywnie [... "38. Malabou podkreśla jednak, że pełniejsze ujęcie tego momentu znajdujemy w Nauce logiki: „To przejście należy więc tu ująć raczej tak, że idea puszcza wolno samą siebie, absolutnie pewna siebie i spokojna w sobie”39. I to właśnie owo „puszczanie się wolno" jest przedmiotem zainteresowania Malabou.

Na pierwszy rzut oka owo puszczenie siebie wolno, owo uchylenie się, jest terminem przeciwstawnym znoszeniu. Ale, jak czytamy, „Spekulatywne uchylenie w żaden sposób nie jest obce procesowi znoszenia, jest nawet jego wypełnieniem. Uchylenie jest zniesieniem znoszenia, wynikiem pracy Aufhebung na sobie, jego transformacją [...], odpuszczeniem sobie znoszenia, które uwalnia się od pewnego szczególnego typu przywiązania" ${ }^{40}$.

Puszczenie wolno, jak skrót procedury skracania, jest związane z rozproszeniem pewnego centrum, które zawiadowało relacyjnością. Skrót był relacją tego, co realne i tego, co idealne. Relacją konstytutywną dla obu jej członów. Każda spekulatywna relacja była produkowaniem opozycji w ich wzajemnym, negatywnym odniesieniu i znoszeniu jej w innych opozycjach, w innych uproszczeniach. Puszczenie wolno jest rozluźnieniem tej sztywności. Dla Malabou kluczowe jest tutaj odniesienie do, związanej z procesem upraszczania, „samowiedzy” jako zwornika generowanych przez uproszczenie sprzeczności. Samowiedza miała być terminem średnim między idealną sferą punktowych zagęszczeń a tym, co w tych zagęszczeniach pulsuje skrytą energią (wielości, heteronomii itd.), między kulturą, system duchowych alienacji, a nieosiagalną dla ducha, ale wciąż „upraszczaną” sferą naturalnej bezpośredniości. I tak długo, jak uproszczenie było jedyną operacją, jaką można było wykonać na owej „bezpośredniości”, przez generowanie „drugiej natury”, bezpośredniości duchowo przyswajalnych, tak długo samowiedza mogła utrzymywać się w swym „idealnym” trwaniu, skazana jednak na rozrywającą ją podwójność nieszczęśliwej świadomości, wariacki pęd złej nieskończoności, wciąż i wciąż zdanej na kolejne uproszczenia. Puszczenie wolno, znoszenie znoszenia, przemienia prostą idealizację: „Spekulatywne puszczenie wolno jest przede wszystkim aktem, w którym «Ja» wyrzeka się siebie, wyrzeka się swej mocy zachowywania i władania. Ale różnica między myśleniem i tym, co pomyślane nie zostaje zatracona w tym puszczeniu wolno. Raczej relacja

38 G.W.F. Hegel Encyklopedia nauk filozoficznych, przeł. Ś.F. Nowicki, PWN, Warszawa 1990, s. 583-584. 
ta zostaje rozmiękczona i upłynniona: jej momenty nie są już dwiema stronami, zamrożonymi i zafiksowanymi w swej opozycyjności”41.

Uproszczenie upraszczania, związanego z podmiotowym centrum, niweluje autonomiczną i wyszczególnioną podmiotowość, przemieniając ją w jeden z „punktów” całego systemu odniesień. Roszczenia zniesienia do objęcia całości w pewnym innym uproszczeniu zostają odwołane. Uproszczenie prezentuje się jako ono samo, i „świadome” swej mechaniki i mechaniczności, uwalnia się od przymusu ciągłego generowania bezpośredniości. Kluczowa wcześniej relacja podmiot-przedmiot, która wikłała się w złą nieskończoność, od tej pory nie zarządza już system, zwalniając go niejako z obowiązku poszukiwania swego spełnienia w jakiejś bezpośredniości. Co więcej - to raczej prezentujący się teraz w nowym świetle system wzajemnych i równoważnych sobie odniesień wytwarza, w jednej ze swych punktowych konstelacji, rzeczoną opozycję podmiotowo-przedmiotową, niestanowiącą już początku ani końca, ani zwieńczenia, ani źródła. Zła nieskończoność od tej pory nie ma już przestrzeni, w której mogłaby się rozwijać, nie ma dokąd pójść. Ruch nie polega na kroczeniu poza, ale na wzajemnym odsyłaniu do siebie tego, co się dzieje.

System zagęszczeń wytwarza się jako nieustanne odniesienia poszczególnych kontrakcji do siebie, jako przelewanie się w siebie, poza horyzontem pełnego uproszczenia czy spełnionej wielości, poza iluzją ostatecznego zniesienia. W tej dziejącej się plastyczności punkty odpuszczają sobie swoją niezależność i ujawniają swoją „istotę” - to, że same są jedynie dynamicznym ruchem uplastyczniania, „znoszenia”, upraszczania, które to procesy retroaktywnie ustanawiają to, co znoszone i upraszczane. System uwalnia w ten sposób magazynowaną w partykularnych, sztucznych „bezpośredniościach” etapów i punktów, energię. Od tej pory nie jest zarządzany przez - zawsze tanatyczne - pragnienie podmiotu, tylko przez coś, co Malabou nazywa „spekulatywnym automatyzmem"42 - przy czym nie chodzi oczywiście o automatyzm martwej maszyny, ale o dzianie się spekulacji samej przez się, o jej wyzwolenie z oków dialektyki końca i początku, źródła i marginesów.

Dwuznaczność dwuznaczności, osiągana w puszczeniu wolno i wyzwoleniu energii systemu do nieprzewidywalnych auto-konfiguracji , to, w świetle analiz Malabou, dialektyka uwolniona od ducha bezpośredniości jako dopełniającego elementu absolutnej podmiotowości. To koniec

Tamże, s. 157. 
zsubstancjalizowanej absolutności i początek absolutu jako plastycznej wzajemności. Proces idealizacji, który z zasady tworzy, zarządza i dąży do pełni, zostaje w nim załamany, ale i podtrzymany. Załamany, bowiem pełnią jest już sam ten proces, a nie jakieś inne, jakiś zewnętrzny wobec niego stan - i na tej samej zasadzie proces ów zostaje podtrzymany. Nie chodzi już w nim jednak o zbawienie od siebie ani spełnienie czy odkupienie, ale o powtarzanie go dla samej powtarzalności, o nawyk, o dzianie się samej podwojonej - reflektywnej - podwójności. Nie było niczego wcześniej niż system-widmo. Sztywność wszelkich „metafizycznych" opozycji ulega w nim radykalnemu rozmyciu - same momenty skrajne są wtórne wobec dziania się ich relacji. Energia, przechowywana w idealizujących zagęszczeniach, staje się energią samego automatycznego systemu, który przez przymus kontrakcji, zawarty w uproszczeniu, energię ową indukował ,z niczego" i teraz, odzyskuje ją, oddaje sobie to, co przed sobą skrywał - swoje radykalne inne jako iluzję bezpośredniości.

Tym jest ostatecznie dwuznaczność, widmowość i plastyczność: samym dzianiem się tego, co się staje. Tylko i aż tyle. Aby nie przesłonić tego wydarzania się spekulacji jako całości tego, co się dzieje, trzeba zarzucić wszelki radykalizm inności. „System nie ma autora”43 - nie ma innego dla widma, nie ma in n e go widma, nie ma żadnej jednoznaczności, nie ma nic, poza procesem plastyczności. 


\section{Abstract}

\section{Maciej A. Sosnowski}

INSTITUTE OF PHILOSOPHY AND SOCIOLOGY OF THE POLISH ACADEMY OF SCIENCES

OtherSpectres

Sosnowski reads Catherine Malabou's The Future of Hegel alongside Derrida's hauntology, or, more broadly speaking, in the context of the modern project initiated by Heidegger, i.e. the deconstruction of the static identity of traditional metaphysics. A key concept here is ambivalence - both for Heidegger, who constructs his criticism of metaphysics around it, and for Derrida, for whom the spectre represents the incarnation/death of ambivalence itself. Malabou's notion of plasticity also tries to capture a certain (non)original doubleness or duality as something that is the motor of all metamorphoses.

\section{Keywords}

ambivalence, doubleness, identity, dialectics, spirit, spectre, placticity, Aufhebung, Georg Wilhelm Friedrich Hegel, Martin Heidegger, Jacques Derrida, Catherine Malabou 